\title{
Multiple Forms of Long-Term Potentiation and Long-Term Depression Converge on a Single Interneuron in the Leech CNS
}

\author{
Brian D. Burrell and Christie L. Sahley \\ Department of Biological Sciences, Purdue University, West Lafayette, Indiana 47907
}

\begin{abstract}
Long-term potentiation (LTP) of synaptic transmission was observed in two types of synapses that converge on the same postsynaptic neuron in the leech CNS. These synapses were made by identifiable sensory neurons, the mechanosensory touch (T-) and pressure (P-) cells, onto the S-cell, an interneuron critical for certain forms of learning. Changes in both the T-S and P-S synapses appear to be activity dependent because LTP was restricted to inputs that had undergone tetanization; however, properties of synaptic plasticity at the T-S and $\mathrm{P}-\mathrm{S}$ connections differ considerably. At the P-S synapse, LTP was induced in the tetanized synapse but not in the nontetanized synapse tested in parallel. P-S LTP was blocked by the NMDA receptor antagonist DL-2-amino-5-phosphono-valeric acid (AP-5) or by lowering the extracellular concentration of glycine, an NMDA receptor (NMDAR) co-agonist. P-S LTP was strongly affected by the initial amplitude of the synaptic potential at the time LTP was induced. Smaller amplitude synapses $(<3.5 \mathrm{mV})$ underwent robust potentiation, whereas the less common, larger amplitude synapse $(>3.5 \mathrm{mV})$ depressed after tetanization. At the T-S synapse, tetanization simultaneously induced homosynaptic LTP in the tetanized input and heterosynaptic long-term depression (LTD) in the input made by a nontetanized T-cell onto the same S-cell. Interestingly, AP-5 failed to block homosynaptic LTP at the T-S synapse but did prevent heterosynaptic LTD. T-S LTP was not affected by the initial EPSP amplitude. Thus, leech neurons exhibit synaptic plasticity with properties similar to LTP and LTD found in the vertebrate nervous system.
\end{abstract}

Key words: long-term potentiation; long-term depression; leech; synaptic plasticity; learning; NMDA

\section{Introduction}

Persistent activity-dependent changes in synaptic transmission, such as long-term potentiation (LTP) or long-term depression (LTD), are thought to play a critical role in learning and subsequent memory formation (for review, see Bear and Linden, 2001; Grimwood et al., 2001; Malenka and Siegelbaum, 2001). This assertion is based on the following observations: (1) LTP and LTD appear to mimic the behavioral properties of associative learning, given that they can be induced by temporal pairing of two inputs that converge on a shared postsynaptic target or by pairing presynaptic and postsynaptic activity (Bear and Linden, 2001; Bi and Poo 2001; Malenka and Siegelbaum, 2001); (2) LTP and LTD exhibit synapse specificity thought to be necessary for proper encoding of learned events (Malenka and Siegelbaum, 2001) (but see Bi and Poo, 1998, 2001); and (3) animals in which LTP or LTD has been disrupted in the brain also exhibit behavioral decrements in learning and memory (for review, see Grimwood et al., 2001). The view that LTP and LTD contribute to learning and memory is not universally accepted (Shors and Matzel, 1997; Zamanillo et al., 1999), however, and it has been diffi-

Received Aug. 4, 2003; revised March 18, 2004; accepted March 18, 2004.

This work was supported by Grant IBN-0213458 from the National Science Foundation (B.D.B.). We thank Drs. Brenda L. Moss, Kenneth J. Muller, and Geoff G. Murphy and three anonymous reviewers for their helpful discussion and Rodney McPhail for Figure 2 illustration.

Correspondence should be addressed to Dr. Brian D. Burrell, Department of Biological Sciences, Purdue University, B320 Lilly Hall, West Lafayette, IN 47907. E-mail: burrell@purdue.edu.

DOI:10.1523/JNEUROSCI.0178-04.2004

Copyright $\odot 2004$ Society for Neuroscience $\quad$ 0270-6474/04/244011-09\$15.00/0 cult to determine the precise relationship between LTP- and LTD-induced changes and network-level changes that must occur in the neural circuits that mediate a specific behavior during learning. This difficulty arises, in part, from the complexity of the mammalian brain (in which LTP and LTD are most often studied), making it difficult to know the functional relevance of an individual neuron to the behavior of interest (Bear and Linden, 2001), and by the fact that neither LTP nor LTD is mediated by a single cellular mechanism (Malenka and Siegelbaum, 2001).

Studies using invertebrates such as the medicinal leech may help to understand better the role of LTP and LTD during learning and memory. Compared with the vertebrate brain, the leech CNS contains far fewer neurons, allowing one to record from single, identifiable neurons and to assess the functional role of a cell for a given behavior. In addition, basic cellular and molecular properties of vertebrate and invertebrate neurons are highly conserved, so that discoveries regarding the structure and function of invertebrate neurons are relevant to understanding vertebrate neurons and vice versa (Burrell and Sahley, 2001).

The presence of LTP was examined at synapses formed by two distinct types of mechanosensory neurons that innervate the leech skin, the touch (T-) and pressure (P-) cells, onto a single interneuron type, the S-cell. The S-cell was chosen because of its role in learning-related behavioral plasticity of the whole-body shortening reflex: the interneuron is critical for the induction and maintenance of sensitization of shortening and also contributes to dishabituation of this reflex (Sahley et al., 1994b; Modney et al., 1997; Burrell et al., 2001, 2003). Given its importance for sensiti- 
zation, the S-cell also may be a site for activity-dependent forms of neuroplasticity thought to contribute to associative types of learning. The $\mathrm{P}$ - and $\mathrm{T}$-cells were chosen because they provide the relevant afferent input to the $\mathrm{S}$-cell during shortening (Shaw and Kristan, 1995). Changes in synaptic transmission at the P-S and $\mathrm{T}-\mathrm{S}$ synapses were examined after the simultaneous tetanization of the P- and T-cells. Modifications of synaptic transmission at the tetanized synapses were compared with nontetanized $\mathrm{P}-\mathrm{S}$ and $\mathrm{T}-\mathrm{S}$ synapses tested in parallel. The two types of inputs onto the S-cell differed in terms of the pattern of synaptic plasticity as well as the underlying cellular mechanisms.

\section{Materials and Methods}

Medicinal leeches (Hirudo medicinalis) weighing $3 \mathrm{gm}$ were obtained from a commercial supplier (Leeches USA Ltd.) and maintained in pond water $\left[0.5 \mathrm{gm} / 1 \mathrm{H}_{2} \mathrm{O}\right.$ Hirudo salt (Leeches USA Ltd.) $]$ at $18^{\circ} \mathrm{C}$. Single ganglia were dissected in leech Ringer's solution containing (in $\mathrm{mM}$ ): 115 $\mathrm{NaCl}, 4 \mathrm{KCl}, 1.8 \mathrm{CaCl}_{2}, 1 \mathrm{MgCl}_{2}$, and $10 \mathrm{HEPES}$, and placed in a recording chamber that was constantly perfused with Ringer's to which $10 \mathrm{~mm}$ glucose and 10-20 $\mu \mathrm{m}$ tubocurare (Sigma, St. Louis, MO) were added. The latter was added to inhibit movement by the ganglion and did not alter in any obvious manner the electrical properties or synaptic transmission of neurons that were studied. In experiments in which high divalent Ringer's was used, concentrations of $\mathrm{CaCl}_{2}$ and $\mathrm{MgCl}_{2}$ were 15 and $18 \mathrm{~mm}$, respectively, each replacing $\mathrm{NaCl}$ mole for mole. Intracellular recordings of individual neurons were made by impaling the cell with a sharp microelectrode made from borosilicate glass ( $1.0 \mathrm{~mm}$ outer diameter, $0.78 \mathrm{~mm}$ inner diameter; FHC, Bowdoinham, ME) and pulled to tip resistance of 20-30 M $\Omega$ using a Sutter P-97 puller (Sutter Instruments). Recordings were made using a BA-1S bridge amplifier (NPI) or an Axoclamp 2A amplifier (Axon Instruments, Foster City, CA) in bridge mode. Extracellular stimulation of segmental nerve roots was made using a suction electrode connected to a Grass S88 stimulator with SIU5 stimulus isolation units (Astromed). Electrophysiological data were viewed on a digital oscilloscope (Tektronix) and stored on a computer using a Digidata 1200 analog-digital interface and Axoscope 8.0 acquisition software (Axon Instruments). Data were subsequently analyzed using Clampfit software (Axon Instruments).

Measurements were made of unitary EPSPs produced by either a single P- or T-cell action potential elicited by intracellular current injection. Membrane potential in the S-cell was held at approximately $-56 \mathrm{mV}$ for P-S EPSP measurements and $-65 \mathrm{mV}$ for $\mathrm{T}-\mathrm{S}$ measurements so that EPSP parameters could be measured without action potential initiations (normal S-cell resting potential is between -40 and $-50 \mathrm{mV}$ ). The S-cell was held at a lower membrane potential for the T-S synapse because T-cell-elicited EPSPs in the S-cell are two to four times larger than those elicited by the P-cell. In the P-S synapse, the peak EPSP amplitude was measured during the first $50 \mathrm{msec}$ after the presynaptic action potential had been elicited. In the T-S synapse, the electrical component of the EPSP was measured as the peak amplitude during the first $10 \mathrm{msec}$, and the polysynaptic, chemical component was measured as the peak amplitude that occurred after this initial period. Paired-pulse facilitation (PPF) at the $\mathrm{P}-\mathrm{S}$ synapses was measured by eliciting two $\mathrm{P}$-cell action potentials at $60 \mathrm{msec}$ intervals and using the peak amplitude in the two resulting S-cell EPSPs to calculate the PPF ratio $\left(\mathrm{EPSP}_{2}-\mathrm{EPSP}_{1} / \mathrm{EPSP}_{1}\right)$ (Alturi and Regehr, 1996). Multiple paired-pulse responses (three to six) were elicited at each synapse, and the averages of the first and second EPSP amplitudes were used to calculate the PPF ratio at each synapse (Kim and Alger, 2001). PPF was not tested in the polysynaptic T-S synapse.

During the initial or pretest stage, EPSPs were elicited in the S-cell by intracellular stimulation of the P- or T-cell that subsequently would undergo tetanization (the dorsal P- or T-cell) and by a separate, nontetanized sensory cell that would act as a control (the ventral P- or T-cell). Both the tetanized and nontetanized afferent neurons were in the same ganglion ipsilateral to each other, and the EPSPs elicited by these neurons were measured in the same postsynaptic S-cell. After the pretest measurements the ganglion was perfused for 10 min with $1 \mu \mathrm{M}$ glycine, which is necessary for NMDAR function (McBain and Mayer, 1994), dissolved in the Ringer's solution described above. In some experiments, the glycine concentration was reduced to $0.1 \mu \mathrm{M}$ or omitted altogether during this stage. In other experiments, $100 \mu \mathrm{M}$ AP-5 (Sigma), an NMDA receptor antagonist, was applied in addition to $1 \mu \mathrm{M}$ glycine. After this $10 \mathrm{~min}$ perfusion period, the dorsal P-and T-cells were simultaneously tetanized while the Ringer's with glycine was still being perfused through the recording chamber. Pilot studies demonstrated that tetanic stimulation of a single P- or T-cell was ineffective at inducing long-lasting changes in synaptic transmission (data not shown) when compared with changes induced by cooperative firing of the T-and P-cell.

Co-tetanization of the dorsal P- and T-cell was accomplished by using a suction electrode to stimulate the cut end of the dorsal-posterior nerve branch (DP nerve) that normally extends from the ganglion to the dorsal skin. Each train of tetanic stimuli consisted of five pulses (1 msec pulse duration) delivered at $25 \mathrm{~Hz}$. Ten trains of tetanic stimuli were delivered at $0.1 \mathrm{~Hz}$. Stimulation of the DP nerve allowed for selective activation of the dorsal P-and T-cells because there are no axons from other touch and pressure neurons in the same ganglion present in this nerve (Nicholls and Baylor, 1968). There are, however, processes in the DP nerve belonging to dorsal P- and T-cells from neighboring ganglia that carry action potentials from minor receptive fields in the skin (Yau, 1976). These processes either were not activated (in the case of the T-cells) or were activated only intermittently (in the case of the P-cells) by DP nerve stimulus (data not shown). Tetanic stimulation of the nerve containing the dorsal P- and T-cells was used because the two afferents could be more effectively co-activated during tetanization by stimulation with a single suction electrode. In addition, tetanization with the suction electrode minimized the time that the two afferents were impaled with a microelectrode and was therefore less invasive. This was important because microelectrode impalement has been observed to disrupt certain types of synaptic plasticity (Eliot et al., 1994). Although the DP nerve may contain other processes with input to the S-cell, they were unlikely to be active given that nociceptive neurons (N-cells) and Retzius cells were not activated directly by suction electrode stimuli to the DP nerve (see Results). Furthermore, even if other S-cell inputs were activated by DP nerve stimuli, their activity apparently is not relevant because potentiation was restricted to the tetanized synapses, with nontetanized synapses remaining unchanged or actually undergoing depression.

After tetanic stimulation, the perfusion solution was switched back to the initial, glycine-free Ringer's solution. Pilot experiments indicated that prolonged exposure to even micromolar concentrations of glycine nonspecifically facilitates synaptic transmission between leech neurons (data not shown), in agreement with published results using millimolar glycine concentrations ( $\mathrm{Wu}, 2002)$. One hour after tetanic stimulation, S-cell EPSPs elicited by intracellular stimulation of the tetanized and nontetanized P- or T-cell inputs were separately retested (posttest) in a manner identical to the pretest measurements. Electrical properties of the S-cell membrane were also tested during the pretest and posttest stages. Input resistance was tested by injecting a $0.5 \mathrm{nA}, 200 \mathrm{msec}$ hyperpolarizing current pulse into the cell and measuring the resulting change in membrane potential. S-cell excitability was tested by injecting a $0.5 \mathrm{nA}$, $400 \mathrm{msec}$ depolarizing current pulse and recording the number of elicited action potentials.

It was not possible to record from the S-cell throughout the pretetanus and post-tetanus periods. In such chronic S-cell recordings, EPSP amplitude progressively decreased regardless of whether the presynaptic input had been tetanized (data not shown). This is likely attributable to the small size of the S-cell $(\sim 10 \mu \mathrm{m})$ and the elasticity of the leech ganglion, making the interneuron easily damaged by the recording electrode as well as other, unknown processes [e.g., the disruptive effect of intracellular recording on synaptic plasticity in Aplysia neurons described by Eliot et al. (1994)]. Therefore, to observe the changes in EPSP amplitude at multiple time points after tetanic stimulation, the P-S synapse was tested in separate groups of ganglia at 5, 30, and $45 \mathrm{~min}$ after tetanic stimulation ( $n=3$ for each group). These experiments were conducted in the same manner as the $1 \mathrm{hr}$ post-tetanus group described previously. 


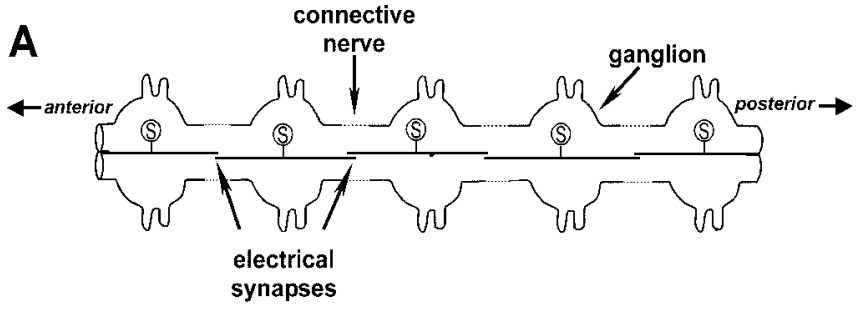

B

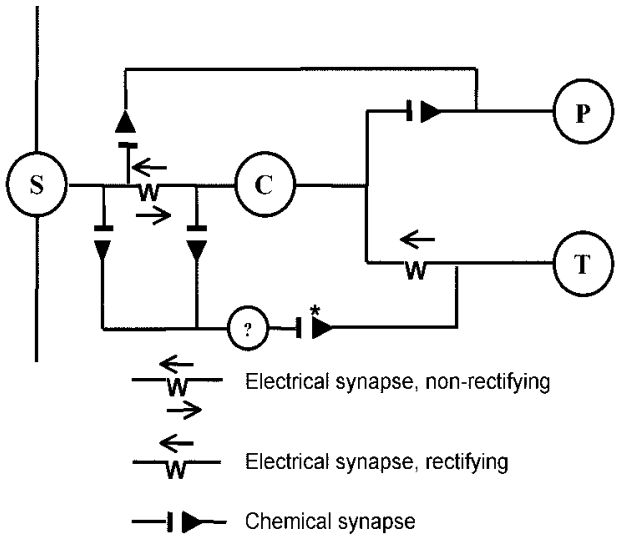

Figure 1. A, Organization of the S-cell network. Each ganglion contains a single $S$-cell that is electrically coupled with the $S$-cells from the adjacent ganglia. B, Synaptic input by the $T$ - and $\mathrm{P}$-cells onto the S-interneuron. Nearly all synaptic input that the S-cell receives from the $\mathrm{T}$ - and P-cells is routed through an interposed interneuron, the coupling $(C-)$ cell, which is strongly coupled to the $S$-cell by a nonrectifying electrical synapse. The P-S synapse has both monosynaptic and polysynaptic (data not shown) inputs. The T-S synapse has both monosynaptic electrical and polysynaptic chemical components. The "?" indicates the unknown neuron(s) that mediates the polysynaptic, chemical component of the T-S synapse. The asterisk indicates that the synaptic connection between the T-cell and an unknown interneuron is presumed to be chemical.

\section{Results}

The leech CNS consists of a chain of 21 ganglia plus fused ganglia in the head and tail sections (Muller et al., 1981; Nicholls et al., 2001). Each ganglion has a single S-interneuron with an axon that projects anteriorly and posteriorly into the connective nerves that link the ganglia (Fig. 1A). Halfway to the next ganglion, these axons make an electrical synapse with axons from the neighboring S-cells, forming a chain or network of S-interneurons that extend throughout the leech CNS. Action potentials initiated in any S-cell propagate reliably in both directions throughout the entire network (Frank et al., 1975).

Nearly all synaptic input from the $\mathrm{T}$ - and $\mathrm{P}$-cells to the $\mathrm{S}$-cell is routed through an interposed interneuron, the coupling $(\mathrm{C}-)$ cell (Fig. $1 B$ ). The S- and C-cells are electrically coupled and EPSPs elicited in the C-cell are carried to the S-cell with little attenuation, essentially acting as monosynaptic EPSPs (Muller and Scott, 1981) and will referred to as such. The P-cells elicit a glutamatergic EPSP onto the S-cell of 1-5 $\mathrm{mV}$ in amplitude that has both monosynaptic and polysynaptic components (Baccus et al., 2000). Most of the monosynaptic contacts by the P-cell are on the coupling interneuron, but a few synapses terminate directly onto the S-cell (Baccus et al., 2000). The T-cell elicits an EPSP that consists of a small (1-2 mV) electrical synapse and a larger (4-8 $\mathrm{mV}$ ) polysynaptic chemical synapse (Muller and Scott, 1981). The identity of the interneuron(s) that contributes to the chemical component of the T-S synapse is not known. The T-cell makes no direct contact with the S-cell, and the T-S electrical synapse is mediated only by contacts between the T- and C-cells. The interneuron(s) that mediates the chemical component of the
T-S connection appears to be make synaptic contacts on both the C- and S-cells (Muller and Scott, 1981).

Tetanic stimuli ( 10 tetani at $0.1 \mathrm{~Hz}$; five pulses per tetanus at $25 \mathrm{~Hz}$ ) were delivered to the DP nerve that contains axons from the dorsal P-and T-cells while the ganglion was perfused with Ringer's that contained $1 \mu \mathrm{M}$ glycine. The other P- and T-cells that are present in the ganglion do not have processes in this nerve (Fig. $2 A$ ). Each stimulus pulse in the tetanus train elicited a single action potential in the $\mathrm{P}$ - and T-cells (Fig. $2 B$ ). Stimulus intensity during tetanization was attenuated so that $\mathrm{N}$-cells with axons in the DP nerve were not activated (Fig. $2 \mathrm{~B}$ ). A single tetanus elicited multiple EPSP-initiated action potentials in the S-cell (Fig. 2 B), demonstrating that DP nerve tetanic stimulation produced coincident initiation of action potentials in the presynaptic and postsynaptic neurons. Serotonergic Retzius cells, which have processes in the DP nerve, were not directly activated by the tetanus, but they were activated synaptically (Fig. $2 B$ ), probably because of input from the P-cell (Szczupak et al., 1993). Retzius cell activity was initially two to three action potentials per tetanus but was depressed to zero to two action potentials with repeated tetani. This activity is not thought to have any effect on the neurons being studied because the amount of activity was less than that observed to have any neuromodulatory effect under similar recording conditions (Burrell et al., 2001).

\section{LTP at the P-S synapse}

The effect of tetanic stimulation on $\mathrm{P}-\mathrm{S}$ synaptic transmission depended on the initial (pretest) EPSP amplitude. Smallamplitude EPSPs $(<3.5 \mathrm{mV})$ (Fig. $3 A$, filled circles) exhibited substantial potentiation, whereas initially large-amplitude EPSPs $(>3.5 \mathrm{mV}$ ) (filled squares) exhibited depression $1 \mathrm{hr}$ after tetanization. This was confirmed statistically when the mean posttetanus changes between small- and large-amplitude synapses were compared (Fig. 3A, inset) (independent $t$ test; $t=12.39$; $p<$ $0.00001)$. There was little or no change in the one intermediateamplitude EPSP $(3.5 \mathrm{mV})$ (Fig. $3 A$, filled triangle) that was tested. It is not clear whether the observed depression in large-amplitude synapses is caused only by the tetanic stimuli, because both the tetanized $(n=4)$ and nontetanized $(n=2$; data not shown) large-amplitude synapses exhibited similar levels of depression at the post-test stage (42 vs $43 \%$, respectively). S-cells from the small and large EPSP amplitude category did not differ in terms of resting potential $(-45.40 \pm 1.81$ vs $-46.25 \pm 1.49 \mathrm{mV}$, respectively), the membrane potential at which the S-cell was held during EPSP measurements ( $56.25 \pm 0.32$ vs $56.25 \pm 0.25 \mathrm{mV}$ ), or input resistance $(16.41 \pm 1.41$ vs $14.74 \pm 1.10 \mathrm{M} \Omega)$ during the pretest stage.

The two types of synapses did differ in terms of the amount of PPF observed at the pretest stage and in changes in PPF after tetanization (Fig. 3B). The mean PPF ratio (see Materials and Methods) during the pretest stage was significantly lower in the large-amplitude synapses relative to the small-amplitude connections (Fig. 3B, inset) (two-way ANOVA with repeated measures; $F=5.71 ; p<0.05$; ANOVA post hoc test; $p<0.001)$ demonstrating that large-amplitude synapses exhibited less facilitation. The amount of PPF is thought to reflect the probability of neurotransmitter release such that the synapses with a lower probability of release exhibit greater PPF and vice versa (Dobrunz and Stevens, 1997; Murthy et al., 1997). This suggests that large-amplitude EPSPs are large, at least in part, because the presynaptic cell has a higher probability of release (as opposed to the postsynaptic cell having more neurotransmitter receptors).

After tetanization, the PPF ratio in small-amplitude synapses 
did not change (Fig. 3B, inset) (ANOVA post hoc test; $p>0.05$ ), indicating that probability of release in the P-cell was not affected by tetanization and suggesting that the observed changes in synaptic transmission involved a postsynaptic mechanism. In large-amplitude synapses on the other hand, post-tetanus PPF increased relative to the pretest levels (Fig. $3 B$, inset) (ANOVA post hoc test; $p<$ 0.001 ), an increase that corresponded with depression at these synapses. Because LTP in the P-S synapse depends on the initial EPSP amplitude and because the largeand small-amplitude synaptic states clearly differ from each other in terms of a number of properties (PPF, effect of tetanization on both EPSP amplitude and $\mathrm{PPF}$ ), subsequent analysis of $\mathrm{P}-\mathrm{S}$ synaptic plasticity will be restricted to synapses in which the initial EPSP amplitude was $<3.5 \mathrm{mV}$. In all P-S synapses tested, this category of synapse was much more common $(n=30)$ than synapses for which the initial EPSP amplitude was $\geq 3.5 \mathrm{mV}$ ( $n=$ 9).

In synapses that were in this initial small-amplitude category, the EPSP elicited by the tetanized $\mathrm{P}$-cell $\left(\mathrm{P}^{+}\right)$was potentiated by an average of $1.75 \pm 0.25 \mathrm{mV}$ $1 \mathrm{hr}$ after tetanization (pretest $=1.80 \pm$ $0.19 \mathrm{mV}$ vs post-test $=3.54 \pm 0.41 \mathrm{mV}$; paired $t=7.02 ; p<0.001 ; n=6)$, an increase of $98 \pm 10.25 \%$ (Figs. $4,5 A$ ). The EPSP elicited in the same S-cell by the nontetanized $\mathrm{P}$-cell $\left(\mathrm{P}^{-}\right)$that was tested in parallel remained unchanged, with only a $0.04 \pm 0.30 \mathrm{mV}$ difference between the pretest and post-test EPSP amplitude $1 \mathrm{hr}$ after tetanus (Figs. 4, 5A) (pretest $=$ $1.89 \pm 0.31 \mathrm{mV}$ vs post-test $=1.93 \pm 0.12$ $\mathrm{mV}$; paired $t=0.14 ; p>0.05 ; n=5)$. Substantial potentiation in the tetanized $\mathrm{P}-\mathrm{S}$ synapse is observed $5 \mathrm{~min}$ after delivery of the tetanus, and the level of potentiation reaches plateau within $30 \mathrm{~min}$ after tetanization (Fig. 4A). These results demonstrate that tetanic stimulation of the DP nerve elicits considerable enhancement in the $\mathrm{P}-\mathrm{S}$ synapse that is persistent and restricted to the P-cell input that had undergone tetanization, features that are consistent with LTP in other animals.

Two types of experiments were performed to determine whether LTP observed at the leech P-S synapse depends on NMDAR activity. In the first set of experiments, the ganglion was perfused with the specific NMDAR antagonist AP-5 (100 $\mu \mathrm{M})$ for $10 \mathrm{~min}$ before and during delivery of the tetanic stimuli. No potentiation of the $\mathrm{P}^{+}$-elicited EPSP was observed in the AP-5treated ganglia $1 \mathrm{hr}$ after tetanization (Fig. $5 \mathrm{~A}$ ) (average $\triangle \mathrm{EPSP}=$ $+0.08 \pm 0.35 \mathrm{mV}$; pretest $=2.04 \pm 0.35 \mathrm{mV}$ vs post-test $=$ $2.16 \pm 0.13 \mathrm{mV}$; paired $t=0.22 ; p>0.05 ; n=5$ ). No changes were observed in the $\mathrm{P}^{-}$synapse that was tested in parallel (Fig. $5 A$ ) (average $\triangle \mathrm{EPSP}=+0.43 \pm 0.33 \mathrm{mV}$; pretest $=2.23 \pm 0.32$

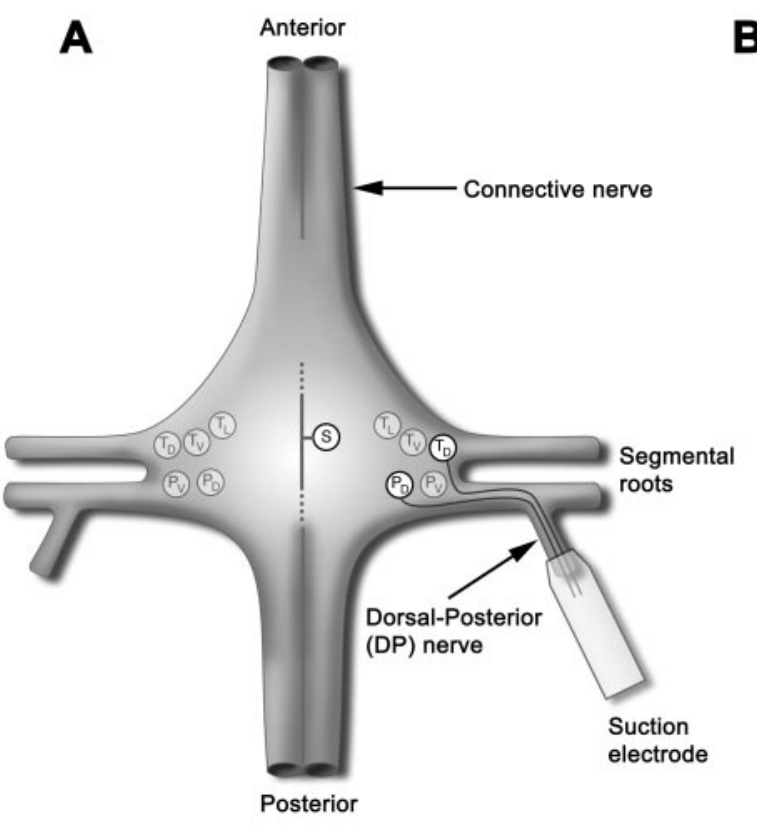

B
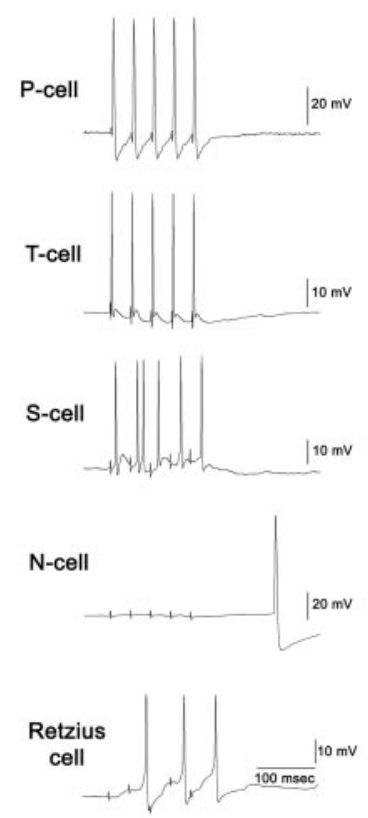

Figure 2. Experimental setup and recordings from presynaptic and postsynaptic neurons during the delivery of a single tetanus. A, A suction electrode was applied to the DP nerve to co-tetanize the dorsal P- and T-cells (highlighted) selectively without activating the other T- and P-cells in the ganglion (shaded) that do not have processes in the DP nerve. The subscripts represent lateral $(\mathrm{L})$, ventral $(\mathrm{V})$, and dorsal $(\mathrm{D})$ and indicate receptive fields in the skin that each sensory neuron innervates. $B$, Sample recordings from the dorsal P- and T-cells, from the postsynaptic S-cell, and from an N-cell and a Retzius cell (which also have
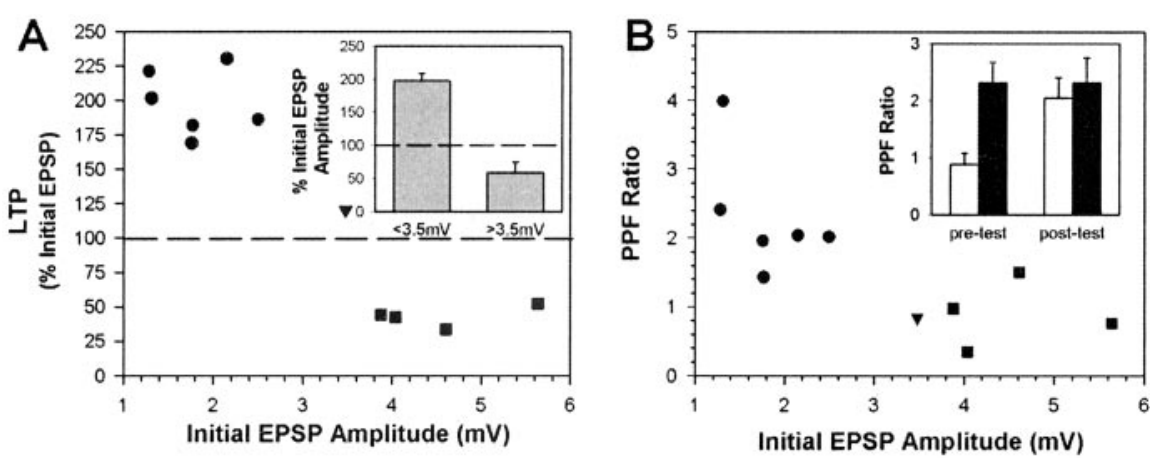

Figure 3. Effect of synaptic state on P-S LTP. A, Changes in synaptic transmission after DP nerve tetanization depended on the initial EPSP amplitude. Small-amplitude synapses (filled circles) potentiated, whereas large-amplitude synapses (filled squares) became depressed. The one synapse of intermediate amplitude (filled triangle) that was tested exhibited little change. Inset, The mean \pm SE percentage change in EPSP amplitude after tetanization was significantly different between the small- and largeInset, In large-amplitude synapses (unfilled bars), the mean \pm SE PPF ratio increased after DP nerve tetanization, but PPF was unchanged in small-amplitude synapses (filled bars).

$\mathrm{mV}$ vs post-test $=2.66 \pm 0.53 \mathrm{mV}$; paired $t=1.28 ; p>0.05 ; n=$ $4)$, indicating that $100 \mu \mathrm{M} \mathrm{AP-5}$ did not affect basal synaptic transmission. Changes in synaptic transmission $(\triangle \mathrm{EPSP})$ attributable to delivery of the tetanus with or without application of AP-5 during tetanization were confirmed using a two-way ANOVA, which indicated a significant interaction effect between the tetanus and the drug treatment $(F=11.15 ; p<0.01)$. Post hoc analysis indicated that the $\triangle$ EPSP in the tetanized synapse in control Ringer's was significantly different from the $\triangle$ EPSP in the nontetanized synapse in control Ringer's $(p<0.01)$ and the tetanized synapse in AP-5 $(p<0.01)$. There was no significant difference between the tetanized and nontetanized synapses that were treated with AP-5 $(p>0.05)$. 

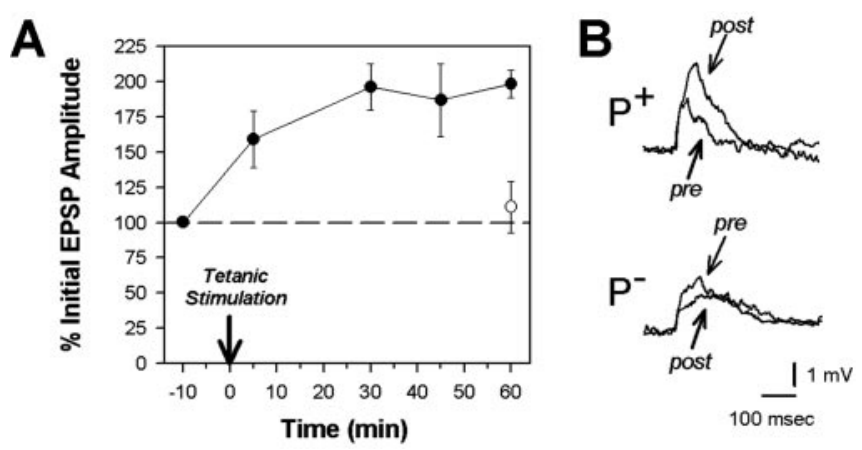

Figure 4. Tetanic stimulation elicits LTP in the P-S synapse that is synapse specific. A, Significant and persistent potentiation was observed in the $\mathrm{P}-\mathrm{S}$ synapse within 5 min after tetanic stimulation. This potentiation did not spread to the synapse formed by a neighboring, ipsilateral P-cell (Fig. 2A) onto the same S-cell, indicating that the P-S LTP was synapse specific. Data are presented as the percentage response of the initial EPSP amplitude (mean $\pm \mathrm{SE}$ ). $B$, Examples of S-cell EPSPs elicited before (pre) and $1 \mathrm{hr}$ after (post) DP nerve tetanization by the tetanized $(+)$ and nontetanized $(-)$ P-cells.
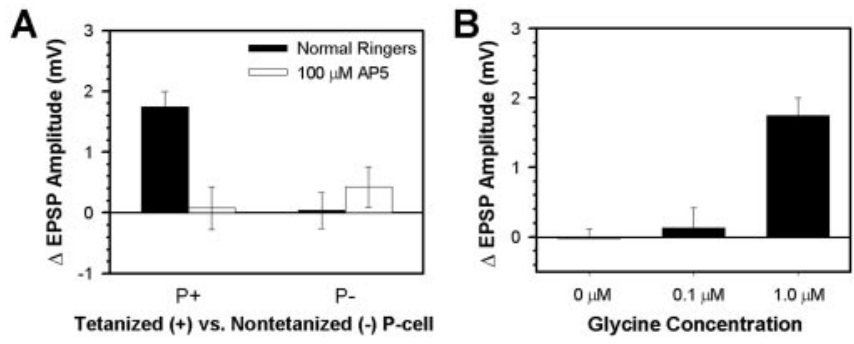

Figure 5. P-SLTP is NMDAR dependent. $A$, In ganglia tested in normal Ringer's (filled bars), P-S LTP was observed in the tetanized synapse $\left(\mathrm{P}^{+}\right)$but not in the nontetanized, control synapse $\left(\mathrm{P}^{-}\right)$. When $100 \mu \mathrm{m} \mathrm{AP-5}$ was added during the tetanization stage (unfilled bars), no changes in EPSP amplitude were observed in either the tetanized or control synapses. Data are presented as the mean \pm SE $\triangle$ EPSP amplitude between the pretest and $1 \mathrm{hr}$ post-test measurements. B, Further evidence of NMDAR involvement in P-S LTP came from experiments in which the level of extracellular glycine was manipulated. In control experiments conducted with $1 \mu \mathrm{m}$ glycine in the leech Ringer's, substantial P-S LTP was observed (same data as control data in Fig. $5 \mathrm{~A}$ ); however, no potentiation was observed when the extracellular glycine concentration was reduced to 0 or $0.1 \mu \mathrm{m}$.

The involvement of NMDARs was investigated in a second manner by taking advantage of the role of glycine as a necessary co-agonist for NMDAR function (McBain and Mayer, 1994). Experiments were performed in which the extracellular concentration of glycine present $10 \mathrm{~min}$ before and during the tetanic stimulation was reduced to $0.1 \mu \mathrm{M}$ or eliminated completely. No potentiation was observed in synapses tetanized with either no glycine $(n=3)$ or $0.1 \mu \mathrm{M}$ glycine $(n=4)$ in the bath (Fig. $5 B$ ) when compared with synapses tetanized in the presence of $1.0 \mu \mathrm{M}$ glycine (one-way ANOVA; $F=15.31 ; p<0.001$ ). Thus, the dependence of P-S LTP on a sufficient extracellular concentration of glycine, along with the ability of AP-5 to block LTP at these synapses, indicates that LTP at the P-S synapse is dependent on NMDAR activity.

To confirm that enhancement of P-cell-elicited EPSPs in the $S$-cell were not the result of changes in the electrical properties of the postsynaptic neuron, S-cell input resistance and excitability (measured as the number of action potentials during a $400 \mathrm{msec}$ injected current pulse) were recorded during both the pretest and post-test stages. Excitability decreased from $9.81 \pm 1.61$ to $9.08 \pm$ 1.77 action potentials per stimulus pulse, whereas input resistance decreased from $16.42 \pm 1.55$ to $15.01 \pm 2.85 \mathrm{M} \Omega$. Both of
A

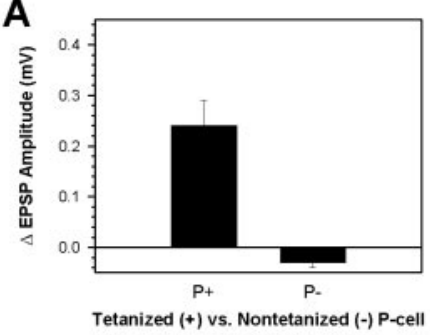

B

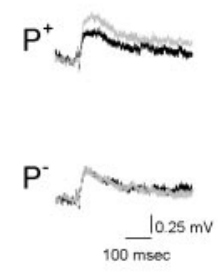

Figure 6. Monosynaptic component of P-S LTP. A, In high divalent Ringer's, LTP was observed in the monosynaptic component of the tetanized synapse $\left(\mathrm{P}^{+}\right)$but not in the nontetanized, control synapse $\left(\mathrm{P}^{-}\right)$. Data are expressed as the $\triangle$ EPSP amplitude (mean $\pm \mathrm{SE}$ ) between the pretest and $1 \mathrm{hr}$ post-test measurements. $B$, Examples of monosynaptic $S$-cell EPSPs elicited before (black trace) and $1 \mathrm{hr}$ after (gray trace) DP nerve tetanization by the tetanized $(+)$ and nontetanized $(-)$ P-cells.

these changes would tend to decrease EPSP amplitude; therefore, potentiation of synaptic transmission was not the result of changes in the intrinsic electrical properties of the postsynaptic neuron.

In experiments conducted in normal Ringer's, it is not possible to determine whether P-S LTP occurs in the monosynaptic or polysynaptic components of the synapse, or in both. Therefore, P-S LTP experiments were repeated with pretest and post-test measurements made in the presence of high divalent Ringer's, which eliminates the polysynaptic component of the synapse (Nicholls and Purves, 1970). The ganglia were bathed in high divalent Ringer's only during the pretest and post-test stages, and Ringer's with normal $\mathrm{Ca}^{2+}$ and $\mathrm{Mg}^{2+}$ concentrations was perfused through the chamber $10 \mathrm{~min}$ before and during tetanic stimulation and for the $1 \mathrm{hr}$ period after. P-cells elicit EPSPs of $0.5-1 \mathrm{mV}$ in the S-cell under these conditions. The reduced EPSP size may be attributable not only to elimination of the polysynaptic component but may also be a result of the elevated $\mathrm{Mg}^{2+}$ levels blocking $\mathrm{Ca}^{2+}$ channels, causing a reduction in transmitter release (Liao and Walters, 2002). In the tetanized synapses, a statistically significant enhancement of $0.24 \pm 0.05 \mathrm{mV}$ was observed (Fig. 6) (pretest $=0.51 \pm 0.03 \mathrm{mV}$ vs post-test $=0.75 \pm$ $0.05 \mathrm{mV}$; paired $t=4.68 ; p<0.05 ; n=3)$, an increase of $48.2 \pm$ $11.2 \%$. In contrast, no change was seen in the nontetanized P-S synapse that was tested in parallel (Fig. 6) (average $\Delta$ EPSP $=$ $-0.02 \pm 0.05$; pretest $=0.70 \pm 0.11 \mathrm{mV}$ vs post-test $=0.68 \pm$ $0.12 \mathrm{mV}$; paired $t=2.22 ; p>0.05 ; n=3)$. These results show that the monosynaptic component does undergo LTP, although the modest amount of potentiation observed in this portion of the $\mathrm{P}-\mathrm{S}$ synapse suggests that under normal conditions the polysynaptic component is also potentiated.

\section{Homosynaptic LTP and heterosynaptic LTD at the T-S synapse}

At the T-S connection, the effects of tetanic stimulation were examined in both the chemical and electrical components of the synapse. In the chemical component of the $\mathrm{T}^{+}$synapse, a modest but statistically significant enhancement of $1.05 \pm 0.43 \mathrm{mV}$ was observed (Fig. $7 A, B)$ (pretest $=7.18 \pm 0.41 \mathrm{mV}$ vs post-test $=$ $8.23 \pm 0.60 \mathrm{mV}$; paired $t=2.43 ; p<0.05 ; n=9$ ), an increase of $15.0 \pm 5.6 \%$. Surprisingly, EPSP amplitude in the $\mathrm{T}^{-}$synapse was significantly depressed by $1.69 \pm 0.51 \mathrm{mV} 1 \mathrm{hr}$ after tetanic stimulation (Fig. $7 A, B$ ) (pretest $=5.68 \pm 0.82 \mathrm{mV}$ vs post-test $=$ $3.99 \pm 0.39 \mathrm{mV}$; paired $t=3.56 ; p<0.05 ; n=6$ ), a decrease of $27.23 \pm 5.27 \%$. Therefore, tetanic stimulation simultaneously induced homosynaptic LTP in the $\mathrm{T}^{+}$synapse and heterosynap- 
tic LTD in the $\mathrm{T}^{-}$synapse. Unlike the $\mathrm{P}-\mathrm{S}$ synapse, potentiation of the chemical component of the T-S synapse did not depend on the initial EPSP amplitude (Fig. 7C). The electrical component of the $\mathrm{T}-\mathrm{S}$ synapse was unchanged by the tetanus in both the $\mathrm{T}^{+}$-elicited EPSPs $(\Delta \mathrm{EPSP}=$ $-0.04 \pm 0.07 \mathrm{mV}$; pretest $=1.49 \pm 0.08$ $\mathrm{mV}$ vs post-test $=1.45 \pm 0.08 \mathrm{mV})$ and the $\mathrm{T}^{-}$-elicited EPSPs $(\Delta \mathrm{EPSP}=-0.16 \pm$ $0.11 \mathrm{mV}$; pretest $=1.31 \pm 0.18 \mathrm{mV}$ vs post-test $=1.15 \pm 0.15 \mathrm{mV}$ ).

The effects of $100 \mu \mathrm{M}$ AP- 5 on synaptic plasticity at the $\mathrm{T}-\mathrm{S}$ connection also yielded surprising results. The NMDAR antagonist did not prevent potentiation at the $\mathrm{T}^{+}$synapse (Fig. 7A). EPSP amplitude increased an average of $1.89 \pm 0.76 \mathrm{mV}$ (pretest $=7.95 \pm 0.58 \mathrm{mV}$ vs post-test $=$ $9.85 \pm 0.83 \mathrm{mV}$; paired $t=2.46 ; p<0.05$; $n=8$ ), an increase of $26.54 \pm 11.88 \%$. Although the average amount of potentiation in the AP-5-treated $\mathrm{T}^{+}$synapses was greater when compared with $\mathrm{T}^{+}$synapses tested in normal Ringer's, this difference was not statistically significant. Depression in the $\mathrm{T}^{-}$synapse, however, was completely blocked in the AP-5treated ganglia (Fig. 7A), with only a $0.10 \pm 0.53 \mathrm{mV}$ decrease (pretest $=5.81 \pm 0.56 \mathrm{mV}$ vs post-test $=5.71 \pm 0.89 \mathrm{mV}$; paired $t=0.13 ; p>0.05 ; n=7)$. No changes were observed in the electrical component of either the $\mathrm{T}^{+}$-elicited EPSPs $(\Delta \mathrm{EPSP}=$ $+0.02 \pm 0.09 \mathrm{mV}$; pretest $=1.74 \pm 0.19 \mathrm{mV}$ vs post-test $=$ $1.76 \pm 0.23 \mathrm{mV})$ or the $\mathrm{T}^{-}$-elicited EPSPs $(\Delta \mathrm{EPSP}=-0.07 \pm$ $0.10 \mathrm{mV}$; pretest $=1.25 \pm 0.16 \mathrm{mV}$ vs post-test $=1.18 \pm 0.13$ $\mathrm{mV})$. Changes in synaptic transmission $(\Delta \mathrm{EPSP})$ caused by delivery of the tetanus with or without application of AP-5 during tetanization were confirmed using a two-way ANOVA, which indicated a significant effect of the tetanus $(F=17.06 ; p<0.001)$ and drug treatment $(F=5.27 ; p<0.05)$. These results indicate that in the chemical component of the T-S synapse, homosynaptic LTP is NMDAR independent, whereas heterosynaptic LTD requires NMDAR activity.

\section{Discussion}

\section{LTP and LTD in the leech CNS}

LTP and LTD were observed in two types of synaptic connections in the leech CNS between identifiable neurons, specifically the mechanosensory T- and P-cells onto the S-cell, an interneuron known to be critical for learning-related behavioral plasticity. LTP at these synapses appears Hebbian in nature, given that tetanization produces coincident activity in the $\mathrm{T}$ - and $\mathrm{P}$-cells and in the S-cell. This will need to be confirmed, however, in future experiments in which action potential initiation in the presynaptic and postsynaptic neurons is controlled independently during LTP induction.

In the P-S synapse, LTP was synapse specific, NMDAR dependent, and dependent on the initial state of the synapse in terms of EPSP amplitude. No change in PPF was observed during P-S LTP, suggesting a postsynaptic mechanism, consistent with several forms of LTP in vertebrates (Luscher et al., 1998; Mainen et al., 1998). P-S LTP was not caused by changes in the intrinsic excitability of the postsynaptic cell given that S-cell input resistance and excitability were not substantially altered after tetanic stimulation. Finally, on the basis of experiments with high divalent Ringer's, LTP enhanced the monosynaptic portion of the P-S synapse; however, the modest level of enhancement suggests that under normal conditions, LTP enhances both the monosynaptic and polysynaptic components of the $\mathrm{P}-\mathrm{S}$ connection.

The dependence of P-S LTP on NMDAR activation is based on the ability of AP-5, an NMDAR antagonist, to block tetanusinduced potentiation and the requirement for sufficient extracellular concentrations of glycine during tetanization. Glycine is a co-agonist that is necessary for NMDAR function (McBain and Mayer, 1994), and NMDARs are sensitive to nanomolar level changes in glycine concentration (Kleckner and Dingledine, 1991). Pharmacological blockade of the co-agonist binding site (Bashir et al., 1990) or elimination of the co-agonist from the extracellular medium (Yang et al., 2003) prevents LTP in vertebrate neurons. The glycine binding site appears to be conserved in invertebrate forms of the NMDAR (Brockie et al., 2001). It was necessary to apply glycine only during the tetanic stimulation because prolonged application nonspecifically increased P-cell synaptic transmission (Wu, 2002; B. D. Burrell, unpublished observations), possibly because application of sufficient amounts of glycine alone can induce LTP (Musleh et al., 1997; Lu et al., 2001; Man et al., 2003). This requirement for phasic application of glycine suggests that its extracellular concentration is regulated in the leech brain as occurs in the vertebrate CNS (Schell et al., 1995; Supplisson and Bergman, 1997; Ahmadi et al., 2003; Yang et al., 2003), but that some element of the experimental protocol disrupted this process.

At T-S synapses, tetanic stimulation simultaneously induced LTP in the tetanized synapse (homosynaptic LTP) and LTD in the control, nontetanized synapse (heterosynaptic LTD). These processes were observed only in the polysynaptic, chemical component of the T-S synapse and not in the monosynaptic, electrical component. AP-5 failed to block homosynaptic LTP but did block heterosynaptic LTD, indicating that LTP is NMDAR independent whereas heterosynaptic LTD is NMDAR dependent. T-S LTP was not affected by the initial amplitude of the T-S EPSP.

This represents the first report of LTP and LTD in the medicinal leech. LTP has been observed in sensorimotor synapses in Aplysia californica (Lin and Glanzman, 1994; Murphy and Glanzman, 1996, 1997, 1999; Antonov et al., 2003) and in the octopus vertical lobe (Hochner et al., 2003). The NMDAR antagonist AP- 5 blocks LTP in Aplysia, indicating the presence of NMDARs in invertebrates that mediate persistent changes in synaptic trans- 
mission. Further evidence of invertebrate NMDARs is found in Drosophila, the cockroach, and Caenorhabditis elegans, where cDNA encoding NMDAR subunits has been isolated (Ultsch et al., 1993; Brockie et al., 2001; Chiang et al., 2002), as well as in unpublished sequences from Aplysia (GenBank accession numbers AY163562, AY234809, AY315153) and the honey bee (AY331183). NMDAR-mediated currents also have been recorded in C. elegans neurons and in the squid chromatophore neuromuscular junction (Brockie et al., 2001; Lima et al., 2003). In the leech, attempts to identify an NMDAR component in the synapse made by the P-cell onto the Anterior Pagoda neuron were unsuccessful, possibly because this particular synapse does not possess NMDARs (Wessel et al., 1999; Wu, 2002).

\section{Effect of "synaptic state" on P-S LTP}

The amount of LTP at the P-S synapse depends on its initial state in terms of amplitude at the time of tetanization: initially smallamplitude synapses undergo substantial potentiation, whereas large-amplitude synapses are depressed. A similar dependence on initial EPSP amplitude has been observed in other systems for both LTP and post-tetanic potentiation (Bi and Poo, 1998; Debanne et al., 1999; Montgomery et al., 2001; Schaffhausen et al., 2001). Large-amplitude P-S synapses also exhibited significantly less PPF than the smaller-amplitude synapses, suggesting that the large-amplitude synapses have a higher probability of neurotransmitter release (Dobrunz and Stevens, 1997; Murthy et al., 1997).

It is not clear how differences in EPSP size affect the capacity of a synapse to undergo LTP. One possibility is that there is a "ceiling effect" and that large-amplitude synapses are incapable of undergoing additional potentiation. This does not explain, however, why some large-amplitude synapses depress after tetanization as observed in leech P-S synapses and in mammalian CA3 hippocampal synapses (Montgomery et al., 2001). In these situations it appears that the previous history of the synapse alters its response to the tetanizing stimuli, resulting in depression. A similar effect of synaptic state is observed in the amygdala, where stimuli that normally elicit LTP can be made to induce LTD after transient potentiation of the synapse (Li et al., 1998). The enhanced transmission observed in initially large-amplitude synapses and their subsequent depression both appear to involve presynaptic modifications on the basis of both the low PPF ratio observed in large-amplitude synapses and the increase in PPF that accompanies their depression. This suggests that the mechanisms synaptic plasticity observed here are distinct from the LTP and LTD processes that involve postsynaptic modifications.

\section{Homosynaptic LTP-heterosynaptic LTD at the T-S synapse}

This is the first report of simultaneous homosynaptic LTP-heterosynaptic LTD in an invertebrate. Homosynaptic LTP-heterosynaptic LTDs have been observed previously in the CA1 (Lynch et al., 1977; Dunwiddie and Lynch, 1978), CA3 (Bradler and Barrioneuvo, 1989; Martinez et al., 2002), and dentate gyrus (Levy and Steward, 1979; Abraham and Goddard, 1983) regions of the hippocampus, in the cortex (Tsumoto and Suda, 1979; Hirsch et al., 1992), and in cultured neuromuscular junctions (Lo and Poo, 1991). In addition, homosynaptic LTP at the T-S synapse is NMDAR independent, a trait that is also observed in the LTP found in various regions of the mammalian brain (Nicoll and Malenka, 1995; Salin et al., 1996; Do et al., 2002a). One surprising feature about the T-S synapse is that although homosynaptic LTP is NMDAR independent, heterosynaptic LTD required NMDAR activity, the reverse of what is typically observed (for review, see Linden and Connor 1995). However, Do et al. (2002b) have observed NMDAR-independent, homosynaptic LTP and NMDAR-dependent, heterosynaptic LTD in perforant path to CA3 hippocampal synapses. T-S homosynaptic LTPheterosynaptic LTD represents an interesting use of bidirectional synaptic plasticity that effectively "tunes" the response of the S-cell to input by the T-cells, increasing the contrast between tetanized and nontetanized inputs as well as ensuring synapse specificity.

It is not known how NMDARs, which are presumably in the tetanized synapse, induce LTD in nontetanized synapses and what signal is transmitted from the tetanized to the nontetanized synapses to produce heterosynaptic LTD. As with homosynaptic LTD, heterosynaptic LTD is thought to require moderate increases in postsynaptic intracellular $\mathrm{Ca}^{2+}$ (Linden and Connor, 1995; Bi and Poo, 1998). Therefore, the following signaling mechanisms are possible: (1) NMDAR activation at tetanized synapses depolarizes nontetanized postsynaptic terminals to a degree that allows a sufficient $\mathrm{Ca}^{2+}$ influx via voltage-gated $\mathrm{Ca}^{2+}$ channels to initiate LTD (voltage signal), or (2) NMDARmediated $\mathrm{Ca}^{2+}$ influx in the tetanized postsynaptic terminal could induce further $\mathrm{Ca}^{2+}$ release from intracellular stores, possibly as a regenerative wave that spreads to the nontetanized synapses $\left(\mathrm{Ca}^{2+}\right.$ signal) (Linden and Connor, 1995; Berridge, 1998; Nishiyama et al., 2000). A second issue to resolve is the loci of homosynaptic LTP-heterosynaptic LTD given that the chemical component of the T-S synapse is polysynaptic. Is the site of plasticity in the T-S synapse at the S-cell, the C-cell, the unknown interneuron that mediates the chemical component of the T-S synapse, or at the T-cell itself?

\section{Conclusions}

Multiple forms of LTP and LTD are observed in synapses in the leech brain that share a common postsynaptic target and have properties very similar to various types of LTP and LTD observed in vertebrates. Although LTP and LTD have received considerable attention regarding their potential role in associative learning in various animals, it is not known whether P-S LTP or T-S homosynaptic LTP-heterosynaptic LTDs contribute to associative learning in the leech. The leech shortening reflex is capable of associative learning (Sahley et al., 1994a), but the cellular processes that mediate this form of learning are not well understood. Serotonin depletion is know to disrupt, but not eliminate, associative learning of leech shortening (Sahley, 1994), suggesting that other types of neuroplasticity, including LTP and LTD, may contribute to this form of learning. Although it is not known whether the $\mathrm{S}$-cell plays a role in associative learning of reflexive shortening, it is an attractive candidate given its critical role for sensitization and full dishabituation of reflexive shortening (Sahley et al., 1994b; Modney et al., 1997; Burrell et al., 2001, 2003). In addition, because the S-interneuron network extends throughout the leech CNS (Fig. $1 A$ ) and receives afferent input from all regions of the leech body, it has the potential to act as a coincidence detector or "association center." Questions about the contribution of the S-cell to associative learning in the leech, specifically the role of P-S LTP and T-S homosynaptic LTPheterosynaptic LTD, can be addressed using semi-intact preparations that allow both behavior and the activity of individual neurons to be monitored at the same time (Burrell et al., 2001).

That multiple cellular processes mediating LTP and LTD may be operating simultaneously in a behavioral context is of considerable interest given the increasing number of mechanisms thought to contribute to the induction and maintenance of LTP 
and LTD. Learning is likely to require multiple forms of LTP and LTD, as well as other types of neuroplasticity, operating simultaneously in the brain. Continued studies of learning in the leech can contribute to our understanding of the properties of these various types of neuroplasticity and how they combine to produce the learning-related changes in behavior.

\section{References}

Abraham W, Goddard G (1983) Asymmetric relationships between homosynaptic long-term potentiation and heterosynaptic long-term depression. Nature 305:717-719.

Ahmadi S, Muth-Selbach U, Lauterbach A, Lipfert P, Neuhuber WL, Zeilhofer HU (2003) Facilitation of spinal NMDA receptor currents by spillover of synaptically released glycine. Science 300:2094-2097.

Alturi PP, Regehr WG (1996) Determinants of the time course of facilitation at the granule cell to Purkinje cell synapse. J Neurosci 16:5661-5671.

Antonov I, Antonova I, Kandel ER, Hawkins RD (2003) Activity-dependent presynaptic facilitation and Hebbian LTP are both required and interact during classical conditioning in Aplysia. Neuron 37:135-147.

Baccus SA, Burrell BD, Sahley CL, Muller KJ (2000) Action potential reflection and failure at axon branch points produce stepwise changes in synaptic transmission to an interneuron essential for learning. J Neurophysiol 83:1693-1700.

Bashir ZI, Tam B, Collingridge GL (1990) Activation of the glycine site in the NMDA receptor is necessary for the induction of LTP. Neurosci Lett 108:261-266.

Bear MF, Linden DJ (2001) The mechanisms and meaning of long-term synaptic depression in the mammalian brain. In: Synapses (Cowan WM, Sudhof TC, Stevens CF, eds), pp 455-517. Baltimore: The Johns Hopkins University.

Berridge MJ (1998) Neuronal calcium signaling. Neuron 21:13-26.

Bi G, Poo M (1998) Synaptic modifications in cultured hippocampal neurons: dependence on spike timing, synaptic strength, and postsynaptic cell type. J Neurosci 18:10464-10472.

Bi G, Poo M (2001) Synaptic modification by correlated activity: Hebb's postulate revisited. Annu Rev Neurosci 24:139-166.

Bradler J, Barrioneuvo G (1989) Long-term potentiation in hippocampal CA3 neurons: tetanized input regulates heterosynaptic efficacy. Synapse 4:132-142.

Brockie PJ, Mellem JE, Hills T, Madsen DM, Maricq AV (2001) The C. elegans glutamate receptor subunit NMR-1 is required for slow NMDAactivated currents that regulate reversal frequency during locomotion. Neuron 31:617-630.

Burrell BD, Sahley CL (2001) Learning in simple systems. Curr Opin Neurobiol 11:757-764.

Burrell BD, Sahley CL, Muller KJ (2001) Non-associative learning and serotonin induce similar bi-directional changes in excitability of a neuron critical for learning in the medicinal leech. J Neurosci 21:1401-1412.

Burrell BD, Sahley CL, Muller KJ (2003) Progressive recovery of learning during the regeneration of a single synapse in the medicinal leech. J Comp Neurol 457:67-74.

Chiang AS, Lin WY, Liu HP, Pszczolkowski MA, Fu TF, Chiu SL, Holbrook GL (2002) Insect NMDA receptors mediate juvenile hormone biosynthesis. Proc Natl Acad Sci USA 99:37-42.

Debanne D, Gahwiler B, Thompson SM (1999) Heterogeneity of synaptic plasticity at unitary CA3-CA1 and CA3-CA3 connections in rat hippocampal slice cultures. J Neurosci 19:10664-10671.

Do VH, Martinez CO, Martinez JL, Derrick BE (2002a) Long-term potentiation in direct perforant path projections to the hippocampal CA3 region in vivo. J Neurophysiol 87:669-678.

Do VH, Kosub KA, Derrick BE (2002b) The glutamatergic NMDA receptor antagonist CPP blocks heterosynaptic LTD at the medial perforant pathCA3 synapse. Soc Neurosci Abstr 28:648.6.

Dobrunz LE, Stevens CF (1997) Heterogeneity of release probability, facilitation, and depletion at central synapses. Neuron 18:995-1008.

Dunwiddie T, Lynch G (1978) Long-term potentiation and depression of synaptic responses in the rat hippocampus: localization and frequency dependence. J Physiol (Lond) 276:353-367.

Eliot LS, Kandel ER, Hawkins RD (1994) Modulation of spontaneous transmitter release during depression and posttetanic potentiation of Aplysia sensorimotor neuron synapses in isolated culture. J Neurosci 14:3280-3292.
Frank E, Jensen JKS, Rinvik E (1975) A multisomatic axon in the central nervous system of the leech. J Comp Neurol 159:1-13.

Grimwood PD, Martin SJ, Morris RGM (2001) Synaptic plasticity and memory. In: Synapses (Cowan WM, Sudhof TC, Stevens CF, eds), pp 519-570. Baltimore: The Johns Hopkins University.

Hirsch J, Barrionuevo G, Crepel F (1992) Homo- and heterosynaptic changes in efficacy are expressed between prefrontal neurons: an in vitro study in rats. Synapse 12:82-85.

Hochner B, Brown ER, Langella M, Shoomrat T, Florito G (2003) A learning and memory area in the octopus brain manifests a vertebrate-like longterm potentiation. J Neurophysiol 90:3547-3554.

Kim J, Alger BE (2001) Random response fluctuations lead to spurious paired-pulse facilitation. J Neurosci 21:9608-9618.

Kleckner NW, Dingledine R (1991) Regulation of hippocampal NMDA receptors by magnesium and glycine during development. Mol Brain Res 11:151-159.

Levy W, Steward O (1979) Synapses as associative memory elements in the hippocampal formation. Brain Res 175:233-245.

Li Y, Field PM, Raisman G (1998) Regeneration of adult rat corticospinal axons induced by transplanted olfactory ensheathing cells. J Neurosci 18:10514-10524.

Liao X, Walters ET (2002) The use of elevated divalent cation solutions to isolate monosynaptic components of sensorimotor connections in Aplysia. J Neurosci Methods 120:45-54.

Lima PA, Nardi G, Brown ER (2003) AMPA/kainate and NMDA-like glutamate receptors at the chromatophore neuromuscular junction of the squid: role in synaptic transmission and skin patterning. Eur J Neurosci 17:507-516.

Lin XY, Glanzman DL (1994) Long-term potentiation of Aplysia sensorimotor synapses in cell culture: regulation by postsynaptic voltage. Proc $\mathrm{R}$ Soc Lond B Biol Sci 255:113-118.

Linden DJ, Connor JA (1995) Long-term synaptic depression. Annu Rev Neurosci 18:319-357.

Lo YJ, Poo MM (1991) Activity-dependent synaptic competition in vitro: heterosynaptic suppression of developing synapses. Science 254:1019-1022.

Lu WY, Man HY, Ju W, Trimble WS, MacDonald JF, Wang YT (2001) Activation of synaptic NMDA receptors induces membrane insertion of new AMPA receptors and LTP in cultured hippocampal neurons. Neuron 243-254.

Luscher C, Malenka RC, Nicoll RA (1998) Monitoring glutamate release during LTP with glial transporter currents. Neuron 21:435-441.

Lynch GS, Dunwiddie T, Gribkoff V (1977) Heterosynaptic depression: a postsynaptic correlate of long-term potentiation. Nature 266:737-739.

Mainen ZF, Jia ZP, Roder J, Malinow R (1998) Use-dependent AMPA receptor block in mice lacking GluR2 suggests postsynaptic site for LTP expression. Nat Neurosci 1:579-586.

Malenka R, Siegelbaum S (2001) Synaptic plasticity: diverse targets and mechanisms for regulating synaptic efficacy. In: Synapses (Cowan WM, Sudhof TC, Stevens CF, eds), pp 393-454. Baltimore, The John Hopkins University.

Man HY, Wang Q, Lu WY, Ju W, Ahmadian G, Liu L, D’Souza S, Wong TP, Taghibiglou C, Lu J, Becker LE, Pei L, Liu F, Wymann MP, MacDonald JF, Wang YT (2003) Activation of PI3-kinase is required for AMPA receptor insertion during LTP of mEPSCs in cultured hippocampal neurons. Neuron 38:611-624.

Martinez C, Do V, Martinez JL, Derrick BE (2002) Associative long-term potentiation (LTP) among extrinsic afferents of the hippocampal CA3 region in vivo. Brain Res 940:86-94.

McBain CJ, Mayer ML (1994) N-methyl-D-aspartic acid receptor structure and function. Physiol Rev 74:723-760.

Modney BK, Sahley CL, Muller KJ (1997) Regeneration of a central synapse restores nonassociative learning. J Neurosci 17:6478-6482.

Montgomery JM, Pavlidis P, Madison DV (2001) Pair recordings reveal allsilent synaptic connections and the postsynaptic expression of long-term potentiation. Neuron 29:691-701.

Muller KJ, Scott SA (1981) Transmission at a "direct" electrical connexion mediated by an interneurone in the leech. J Physiol (Lond) 311:565-583.

Muller KJ, Nicholls JG, Stent GS (1981) Neurobiology of the leech. Cold Spring Harbor, NY: Cold Spring Harbor Laboratory.

Murphy GG, Glanzman DL (1996) Enhancement of sensorimotor connec- 
tions by conditioning-related stimulation in Aplysia depends upon postsynaptic $\mathrm{Ca}^{2+}$. Proc Natl Acad Sci USA 93:9931-9936.

Murphy GG, Glanzman DL (1997) Mediation of classical conditioning in Aplysia californica by long-term potentiation of sensorimotor synapses. Science 278:467-471.

Murphy GG, Glanzman DL (1999) Cellular analog of differential classical conditioning in Aplysia: disruption by the NMDA receptor antagonist DL-2-amino-phosphonovalerate. J Neurosci 19:10595-10602.

Murthy VN, Sejnowski TJ, Stevens CF (1997) Heterogeneous release properties of visualized individual hippocampal synapses. Neuron 18:599-612.

Musleh W, Bi X, Tocco G, Yaghoubi S, Baudry M (1997) Glycine-induced long-term potentiation is associated with structural and functional modifications of $\alpha$-amino-3-hydroxyl-5-methyl-4-isoxazoleproprionic acid receptors. Proc Natl Acad Sci USA 94:9451-9456.

Nicholls JG, Baylor DA (1968) Specific modalities and receptive fields of sensory neurons in CNS of the leech. J Neurophysiol 31:740-756.

Nicholls JG, Purves D (1970) Monosynaptic chemical and electrical connexions between sensory and motor cells in the central nervous system of the leech. J Physiol (Lond) 209:647-667.

Nicholls JG, Martin AR, Wallace BG, Fuchs PA (2001) From neuron to brain. Sunderland, MA: Sinauer.

Nicoll RA, Malenka RC (1995) Contrasting properties of two forms of longterm potentiation in the hippocampus. Nature 377:115-118.

Nishiyama M, Hong K, Mikoshiba K, Poo M, Kato K (2000) Calcium stores regulate the polarity and input specificity of synaptic modification. Nature 408:584-588.

Sahley CL (1994) Serotonin-depletion impairs but does not eliminate classical conditioning in the leech Hirudo medicinalis. Behav Neurosci 108:1043-1052.

Sahley CL, Boulis NM, Schurman B (1994a) Associative learning modifies the shortening reflex in the semi-intact leech Hirudo medicinalis: effects of pairing, predictability, and CS preexposure. Behav Neurosci 108:340-346.

Sahley CL, Modney BK, Boulis NM, Muller KJ (1994b) The S cell: an interneuron essential for sensitization and full dishabituation of leech shortening. J Neurosci 14:6715-6721.

Salin PA, Malenka RC, Nicoll RA (1996) Cyclic AMP mediates a presynaptic form of LTP in cerebellar parallel fiber synapses. Neuron 16:797-803.
Schaffhausen JH, Fischer TM, Carew TJ (2001) Contribution of postsynaptic $\mathrm{Ca}^{2+}$ to the induction of posttetanic potentiation in the neural circuit for siphon withdrawal in Aplysia. J Neurosci 21:1739-1749.

Schell MJ, Molliver ME, Snyder SH (1995) D-serine, an endogenous synaptic modulator: localization to astrocytes and glutamate-stimulated release. Proc Natl Acad Sci USA 92:3948-3952.

Shaw BK, Kristan WBJ (1995) The whole-body shortening reflex of the medicinal leech: motor pattern, sensory basis, and interneuronal pathways. J Comp Physiol [A] 177:667-681.

Supplisson S, Bergman C (1997) Control of NMDA receptor activation by a glycine transporter co-expressed in Xenopus oocytes. J Neurosci 17:4580-4590.

Szczupak L, Jordan S, Kristan Jr WB (1993) Segment-specific modulation of the electrophysiological activity of the leech Retzius neurons by acetylcholine. J Exp Biol 183:115-135.

Tsumoto T, Suda K (1979) Cross-depression: an electrophysiological manifestation of binocular competition in the developing visual cortex. Brain Res 168:190-194.

Ultsch A, Schuster CM, Laube B, Betz H, Schmitt B (1993) Glutamate receptors of Drosophila melanogaster: primary structure of a putative NMDA receptor protein expressed in the head of the adult fly. FEBS Lett 324:171-177.

Wessel R, Kristan WB, Kleinfeld D (1999) Dendritic $\mathrm{Ca}^{2+}$-activated $\mathrm{K}^{+}$ conductances regulate electrical signal propagation in an invertebrate neuron. J Neurosci 19:8319-8326.

Wu E (2002) Evidence against the presence of NMDA receptors at a central glutamatergic synapse in leeches. Invert Neurosci 4:157-164.

Yang Y, Ge W, Chen Y, Zhang Z, Shen W, Wu C, Poo M, Duan S (2003) Contribution of astrocytes to hippocampal long-term potentiation through release of D-serine. Proc Natl Acad Sci USA 100:1519415199.

Yau KW (1976) Receptive fields, geometry and conduction block of sensory neurons in the central nervous system of the leech. J Physiol (Lond) 263:513-538.

Zamanillo D, Sprengel R, Hvalby O, Jensen V, Burnashev N, Rozov A, Kaiser KMM, Koster HJ, Borchardt T, Worley P, Lubke J, Frotscher M, Kelly PH, Sommer B, Andersen P, Seeburg PH, Sakman B (1999) Importance of AMPA receptors for hippocampal synaptic plasticity but not for spatial learning. Science 284:1805-1811. 